\title{
Sugarcane yellow leaf virus Infection Leads to Alterations in Photosynthetic Efficiency and Carbohydrate Accumulation in Sugarcane Leaves
}

\author{
Marcos C. Gonçalves ${ }^{1}$, Jorge Vega ${ }^{2}$, Jurandi G. Oliveira ${ }^{3}$ \& Mara M. A. Gomes $^{3}$ \\ ${ }^{1}$ Centro de Sanidade Vegetal, Instituto Biológico, Av. Conselheiro Rodrigues Alves 1252, CEP 04014-002, São Paulo, SP, \\ fax: (11) 50871793; e-mail: mcgon@biologico.sp.gov.br; ${ }^{2}$ Departamento de Fisiologia Vegetal, IB, UNICAMP, Cx. Postal 6109, \\ CEP 13083-970 Campinas, SP; ${ }^{3}$ Laboratório de Melhoramento Genético Vegetal, Universidade Estadual do Norte Fluminense, \\ CEP 28015-620, Campos dos Goytacazes, RJ
}

(Accepted for publication on 30/11/2004)

Corresponding author: Marcos C. Gonçalves

GONÇALVES, M.C., VEGA, J., OLIVEIRA, J.G. \& GOMES, M.M.A. Sugarcane yellow leaf virus infection leads to alterations in photosynthetic efficiency and carbohydrate accumulation in sugarcane leaves. Fitopatologia Brasileira 30:10-16. 2005.

\begin{abstract}
Infection by Sugarcane yellow leaf virus (ScYLV) causes severe leaf symptoms in sugarcane (Saccharum spp.) hybrids, which indicate alterations in its photosynthetic apparatus. To gain an overview of the physiological status of infected plants, we evaluated chlorophyll $a$ fluorescence and gas exchange assays, correlating the results with leaf metabolic surveys, i.e., photosynthetic pigments and carbohydrate contents. When compared to healthy plants, infected plants showed a reduction in potential quantum efficiency for photochemistry of photosystem (PSII) and alterations in the filling up of the plastoquinone (PQ) pool. They also showed reduction in the $\mathrm{CO}_{2}$ net exchange rates, probably as a consequence of impaired quantum yield. In addition, reductions were found in the contents of photosynthetic leaf pigments and in the ratio chlorophyll $a /$ chlorophyll $b(\operatorname{chl} a / \mathrm{chl} b)$. Carbohydrate content in the leaves was increased as a secondary effect of the ScYLV infection. This article discusses the relation of virus replication and host defense responses with general alterations in the photosynthetic apparatus and in the metabolism of infected plants.
\end{abstract}

Additional keywords: Luteoviridae, carbon metabolism, photoinhibition, virus symptoms.

\section{RESUMO}

Infecção pelo Sugarcane yellow leaf virus causa alterações na eficiência fotossintética e acúmulo de carboidratos nas folhas de cana-de-açúcar

O vírus do amarelecimento foliar da cana-de-açúcar (Sugarcane yellow leaf virus, ScYLV) causa sintomas foliares severos e típicos de infecção por luteovirus, em cana-de-açúcar (Saccharum spp.). Uma vez que alterações no sistema fotossintético da planta seriam esperadas, avaliaram-se a análise da emissão da fluorescência da clorofila $a$ e as trocas gasosas durante a fotossíntese, relacionando esses dados com análises metabólicas, ou seja, conteúdos de pigmentos fotossintéticos e carboidratos presentes nas folhas. As plantas infetadas apresentaram redução na eficiência quântica fotoquímica potencial do fotossistema II (PSII) e alterações no preenchimento do pool de plastoquinona (PQ). Essas plantas apresentaram, também, redução nas taxas de troca líquida de $\mathrm{CO}_{2}$, provavelmente em conseqüência da redução na eficiência quântica. Paralelamente, reduções nos conteúdos de pigmentos fotossintéticos foliares e na razão clorofila $a /$ clorofila $b(\mathrm{chl} a / \mathrm{chl} b)$ foram verificadas. Adicionalmente, o conteúdo de açúcares nas folhas foi aumentado, provavelmente como um efeito secundário da infecção viral. A relação entre a replicação viral e as respostas de defesa da hospedeira com as alterações encontradas no aparelho fotossintético e no metabolismo das plantas infetadas é discutida.

Additional keywords: Luteoviridae, metabolismo do carbon, foto-inibição, sintomas de vírus.

\section{INTRODUCTION}

Over the years, several works have discussed the effects of viruses upon the physiology of diseased plants. However, the general mechanisms that leads to metabolic perturbations and symptom development following viral infection are poorly understood, partially because evolution of the infectious process is difficult to accompany primarily because its physiological consequences are quite variable (Zaitlin and Hull, 1987; Balachandran et al., 1997). It is well known that the onset of leaf symptoms caused by plant viruses in their hosts depends on localised changes in the chloroplast structure and function. The study of the photosystem II $\left(\mathrm{PS}_{\mathrm{II}}\right)$ quantum yield provides a useful model with valuable information about physiological and metabolic conditions of the photosynthetic apparatus. Recent progress in this area has been reached using chlorophyll $a(\mathrm{Chl} a)$ fluorescence and other analyses of the photosynthetic process. Direct evidence that virus infection affects the photosynthetic function over a broad spectrum has been 
Sugarcane yellow leaf virus infection leads to alterations in...

obtained from studies with tobacco (Nicotiana tabacum L.) plants infected with Tobacco mosaic virus (TMV) genus Tobamovirus (van Kooten et al., 1990; Balachandran \& Osmond, 1994; Seo et al., 2000). Various results indicate increase in non-photochemical quenching of fluorescence and reduction in the fraction of open reaction centres, leading to an increased reduction state of the primary electron transport acceptor quinone $A\left(Q_{A}\right)$. This suggests pronounced photo inhibitory processes following viral infection and symptom development. In addition to the influence on the photosynthetic processes, other studies with transgenic plants expressing the movement protein of TMV have shown its effects on carbon metabolism, altering carbohydrate partitioning and plasmodesmal function between mesophyll cells (Balachandran et al., 1995; Lucas et al., 1996; Olesinski et al., 1996). Similar results arose from studies with transgenic tobacco plants expressing the movement protein of Potato leafroll virus (PLRV), family Luteoviridae, genus Potyvirus (Herbers et al., 1997). The source leaves of the transgenic plants showed accumulation of carbohydrates leading to a decrease in photosynthetic capacity, probably due to decreased expression of photosynthetic proteins. An inhibitory feedback mechanism was postulated to be responsible for decreasing photosynthetic gene expression, since the reduction in photosynthesis was restricted to leaves with high carbohydrate content. In plants expressing the luteoviral movement protein (MP17), plasmodesmal alterations took place in the phloem tissue, while plasmodesmata in the mesophyll were indistinguishable from the wild-type (Herbers et al., 1997). In addition, Hofius et al. (2001) demonstrated that the plasmodesmal targeting and gating capacity of MP17 is not influenced by protein amount, whereas changes in carbohydrate status and viral resistance follow a protein level-dependent mechanism. Corroborating these findings, Herbers et al. (2000) described apoplastic sucrose accumulation in tobacco plants infected with Potato virus Y (PVY) family Potyviridae, genus Potyvirus. These authors proposed a role for cell wall invertase in up-regulating the accumulation of soluble sugars and down-regulating photosynthesis, thus strengthening defence responses against viral attack.

In the present study we established an overview of the physiological condition of sugarcane plants (Sacharum spp.) hybrids infected with Sugarcane yellow leaf virus (ScYLV), a novel member of the family Luteoviridae (Maia et al., 2000; Moonan et al., 2000). Infection by ScYLV causes severe symptoms in field and greenhouse grown sugarcane. These symptoms are characterized by intense yellowing of the midrib on the abaxial surface of mature leaves. Older leaves show a red coloration of the midrib on the adaxial surface. Afterwards the leaf blade becomes bleached, proceeding from the tip toward the base of the leaf, and tissue necrosis can eventually take place. Production of sucrose is significantly reduced in infected plants (Vega et al., 1997). Since influence on photosynthetic apparatus could be expected because of the observed symptoms, we used chlorophyll fluorescence assays, correlating the results with other physiological and metabolic surveys, e.g., photosynthetic pigments content, $\mathrm{CO}_{2}$ assimilation and carbohydrate contents, in order to evaluate the physiological status of the ScYLV infected plant.

\section{MATERIALAND METHODS}

\section{Plant material and maintenance}

Sugarcane plants, cultivar SP71-6163, proceeding from stalks of symptomatic ScYLV infected plants, were grown in pots in a greenhouse under natural sunlight. Infection by ScYLV was confirmed by DAS-ELISA using a specific antiserum raised against the virus. Plants of the same cultivar proceeding from meristem tip culture, grown in an insectprotected greenhouse were used as healthy controls. Plants were fertilized on a regular basis and grown for six-eight months, when the first symptoms of midrib yellowing were visible. At this stage chlorophyll fluorescence and gas exchange measurements were performed on the $4^{\text {th }}$ or $5^{\text {th }}$ fully expanded leaves. The pigment and sugar contents were determined in the same leaves. Eighteen replications per treatment (ScYLV infected and healthy plants) were taken for all the following analyses.

\section{Gas exchange measurements}

Gas exchange measurements were performed using an infrared gas analyser LI6200 (LICOR, Nebraska, USA) in the individual attached leaves previously mentioned. Plants were exposed to direct sunlight from 11:50 AM to 2:30 PM, when temperatures varied between 34.5 and $36.7^{\circ} \mathrm{C}$, and to air $\mathrm{CO}_{2}$ concentrations. Incident photosynthetically photon flux density (PPFD), air and leaf temperature inside the chamber enclosing the leaf blade were measured concurrently with $\mathrm{CO}_{2}$ uptake. Measurements were also taken under controlled conditions of $24^{\circ} \mathrm{C}$ and PDFD of $1246 \pm 33 \mu \mathrm{mol} . \mathrm{m}^{-2} \cdot \mathrm{s}^{-1}$.

\section{Chlorophyll fluorescence measurements}

In vivo chlorophyll $a$ fluorescence in intact individual leaves of sugarcane plants was measured after exposure to direct sunlight for $5 \mathrm{~h}$. Before measurements, the leaves were dark-adapted for at least $50 \mathrm{~min}$, and the recording time was of $5 \mathrm{~s}$. Measurements were performed at temperatures of 35 $\pm 1.5^{\circ} \mathrm{C}$ in vivo and in situ using a portable fluorometer PEA (Plant Efficiency Analyser, Hansatech Instruments Ltd., Norfolk, England) with saturation light pulse of about 3,000 $\mu \mathrm{mol} . \mathrm{m}^{-2} \cdot \mathrm{s}^{-1}$. The parameters recorded were initial fluorescence $\left(\mathrm{F}_{0}\right)$, maximum fluorescence $\left(\mathrm{F}_{\mathrm{M}}\right)$, variable fluorescence $\left(\mathrm{F}_{\mathrm{V}}\right)$ and the ratio of variable to maximal fluorescence $\left(\mathrm{F}_{\mathrm{V}} / \mathrm{F}_{\mathrm{M}}\right)$. The ratio $\mathrm{F}_{\mathrm{V}} / \mathrm{F}_{\mathrm{M}}$ was used to assess the quantum efficiency for photochemistry of PSII (Björkman \& Demmig, 1987; Krause \& Weis, 1991; Oliveira et al., 2002).

Chlorophyll $a$ fluorescence transients were evaluated according to the model of Strasser et al. (1995). The fluorescence induction kinetics was plotted by transferring data from the memory of the PEA to a PC and the Origin ${ }^{\circledR} 6.0$ 
M.C. Gonçalves et al.

software. The instrument allows data recording in time intervals of microseconds ( $\mu s)$ and a built-in routine is used to extrapolate the signal of $\mathrm{F}_{0}$; we standardised the fluorescence signal at $60 \mu \mathrm{s}$ as $\mathrm{F}_{0}$. A logarithmic time scale was used for better visualisation of changes in the fluorescence kinetics. This allows showing the levels between $\mathrm{F}_{0}$ and $\mathrm{F}_{\mathrm{M}}$, named $\mathrm{F}_{\mathrm{I}}$ and $\mathrm{F}_{\mathrm{J}}$. In order to standardise the nomenclature of the $\mathrm{Chl} a$ fluorescence transients we used the symbols $\mathrm{F}_{0}-\mathrm{F}_{\mathrm{J}}-\mathrm{F}_{\mathrm{I}}-\mathrm{F}_{\mathrm{P}}$ for the sequence of events following the onset of excitation light, as suggested by Strasser et al. (1995).

\section{Pigment and sugar contents}

To study the influence of ScYLV infection on metabolism of pigments in sugarcane and gain a general overview of the photosynthetic apparatus, chlorophylls $a$ $(\operatorname{chl} a)$ and $b(\operatorname{chl} b)$, xanthophylls plus carotenoid contents, and the ratio $\mathrm{chl} a / \mathrm{chl} b$ were determined. Pigment assays were performed in leaf discs of $7 \mathrm{~mm}$ diameter punched from the same leaves used for fluorescence and gas exchange measurements. Extractions of pigments were performed in methanol:chloroform: water (MCW) medium, in the ratio 12:5:3 $\mathrm{MCW}$. Leaf discs were dried at $80^{\circ} \mathrm{C}$ and weighed individually. Aliquots of the extracts were diluted in ethanol $96 \%$ and the contents of chlorophylls $a$ and $b$ and total carotenoids determined according to Lichtenthaler \& Wellburn (1983). Chloroform and water in the ratio 4:1:1.5 (extract:chloroform: water) were added to a second aliquot of the extracts, and the aqueous phase was used for determination of sugars. Total soluble sugars were determined according to Dubois et al. (1956) and sucrose content was assayed using the anthrone method (van Handel, 1968). The concentration of reducing sugar was calculated by subtracting total soluble sugar contents from sucrose contents. The pigment and sugar contents were expressed in microgram per milligram of dry mass.

\section{RESULTS}

Parameters of $\mathrm{Chl}$ a fluorescence indicate photo inhibition ScYLV infected plants showed increase in the $\mathrm{F}_{0}$ and reduction in the $\mathrm{F}_{\mathrm{M}}$ fluorescence parameters (Figure 1). The efficiency by which excitation energy is harvested and utilised by $\mathrm{PS}_{\mathrm{II}}$ reaction centres is named the quantum yield and can be estimated by the ratio $\mathrm{F}_{\mathrm{V}} / \mathrm{F}_{\mathrm{M}}$, reflecting the quantum efficiency for photochemistry of $\mathrm{PS}_{\mathrm{II}}$. As shown in Figure 1, this ratio was reduced in infected plants.

\section{Kinetics of the $\mathrm{Chl}$ a fluorescence}

The rise of the initial fluorescence to the maximum yield $\left(\mathrm{F}_{0}\right.$ to $\mathrm{F}_{\mathrm{M}}$ ) occurs concomitantly to redox changes of the electron acceptors of PSII, $\mathrm{Q}_{\mathrm{A}}$ and $\mathrm{Q}_{\mathrm{B}}$, and the plastoquinone (PQ) pool. After the dark adaptation causing full oxidation of $Q_{A}$ and $Q_{B}$ the reaction centres of PSII are open. Upon light excitation, $Q_{A}$ becomes reduced and transfers electrons to $Q_{B}$. The first level of fluorescence kinetics, $\mathrm{F}_{\mathrm{J}}$, reflects the equilibrium $\mathrm{Q}_{\mathrm{A}}-\mathrm{Q}_{\mathrm{B}} \Leftrightarrow \mathrm{Q}_{\mathrm{A}} \mathrm{Q}_{\mathrm{B}}-$ (Strasser et al., 1995). During the elevation of the $F_{J}$ to the $F_{P}$ level the $P Q$ pool is successively reduced by $\mathrm{Q}_{\mathrm{B}}--$ to $\mathrm{PQH}_{2}$. At the level $\mathrm{F}_{\mathrm{P}}$, correspondent to the maximum fluorescence, $Q_{A}, Q_{B}$ and the PQ pool are entirely reduced by the PSII; the reaction centres of PSII are then closed. The onset of photosystem I (PSI) triggers the reoxidation of $Q_{A}, Q_{B}$ and $P Q$ pool and the fluorescence slowly decreases to a steady-state level. The time frame correspondent to the fluorescence induction kinetics from $\mathrm{F}_{0}$ to $\mathrm{F}_{\mathrm{p}}$, named fast fluorescence rise (Lichtenthaler and Rinderle, 1988), provided us some insights on the alterations in the photosynthetic apparatus of the infected plants.

The rapid fluorescence induction kinetics of healthy and infected plants by $\mathrm{F}_{0}-\mathrm{F}_{\mathrm{J}}-\mathrm{F}_{\mathrm{I}}-\mathrm{F}_{\mathrm{P}}$ transients (Figure 2). The first phase, $\mathrm{F}_{0}$ to $\mathrm{F}_{\mathrm{J}}$, called the photochemical phase, is light intensity dependent and conducts reduction of $\mathrm{Q}_{\mathrm{A}}$ to $\mathrm{Q}_{\mathrm{A}}-$, whereas the phase correspondent to $\mathrm{F}_{\mathrm{J}}-\mathrm{F}_{\mathrm{I}}-\mathrm{F}_{\mathrm{P}}$ is the nonphotochemical phase. The variations observed between the intermediate transient, $\mathrm{F}_{\mathrm{I}}$, and final, $\mathrm{F}_{\mathrm{P}}$, reflect different redox states of $Q_{B}\left(Q_{A} Q_{B}--\right.$ or $\left.Q_{A}-Q_{B}--\right)$ and the presence of several types of PSII complexes biochemically different that reduce the PQ pool. In $\mathrm{F}_{\mathrm{I}}$ transient, the PQ pool is filled and in $\mathrm{F}_{\mathrm{P}}$ all the molecules are reduced to $\mathrm{PQH}_{2}$. The differences between the kinetics curves of infected and healthy plants after the level $\mathrm{F}_{\mathrm{P}}$ correspond to the phase named slow fluorescence decline. Nevertheless, this phase reaches a steady-state level, T, which is not shown in the graphics because of the short time period ( $5 \mathrm{~s}$ ) used for our readings.

\section{Gas exchange performance}

Results showed a clear reduction in the $\mathrm{CO}_{2}$ exchange rate of the infected plants (Figure 3). Measurements performed in the field indicated a high influence of the photosynthetically photon flux density (PPDF) and temperature, positively correlated to the differences observed in the rates between healthy and infected plants. The $\mathrm{CO}_{2}$ exchange rates are presented by means of light response curves adjusted by polynomial regression (Figure 4). These kinds of analyses verify that healthy plants used light more efficiently to assimilate $\mathrm{CO}_{2}$. The infected plants seem to respond positively to an increase in PPDF until a value of $1,600 \mu \mathrm{mol} \cdot \mathrm{m}^{-2} \cdot \mathrm{s}^{-1}$, after which some plants began to respond negatively in terms of gas exchange (data not shown).

\section{Reduction in photosynthetic pigments contents}

Reduction in the contents of chla and chlb, xanthophylls plus carotenoids and in the ratio chla/chl $b$ was found in the infected plants grown under greenhouse conditions (Figure 5).

\section{Changes in sugar contents in source leaves}

The reduction in the content of sucrose in stalks is probably an effect of the low $\mathrm{CO}_{2}$ exchange rates in infected sugarcane plants. On the other hand, a diverse prognostic is expected in source leaves of plants infected by luteoviruses. In order to verify the impact of ScYLV on the metabolism of carbohydrates in sugarcane leaves we determined the 
Sugarcane yellow leaf virus infection leads to alterations in...
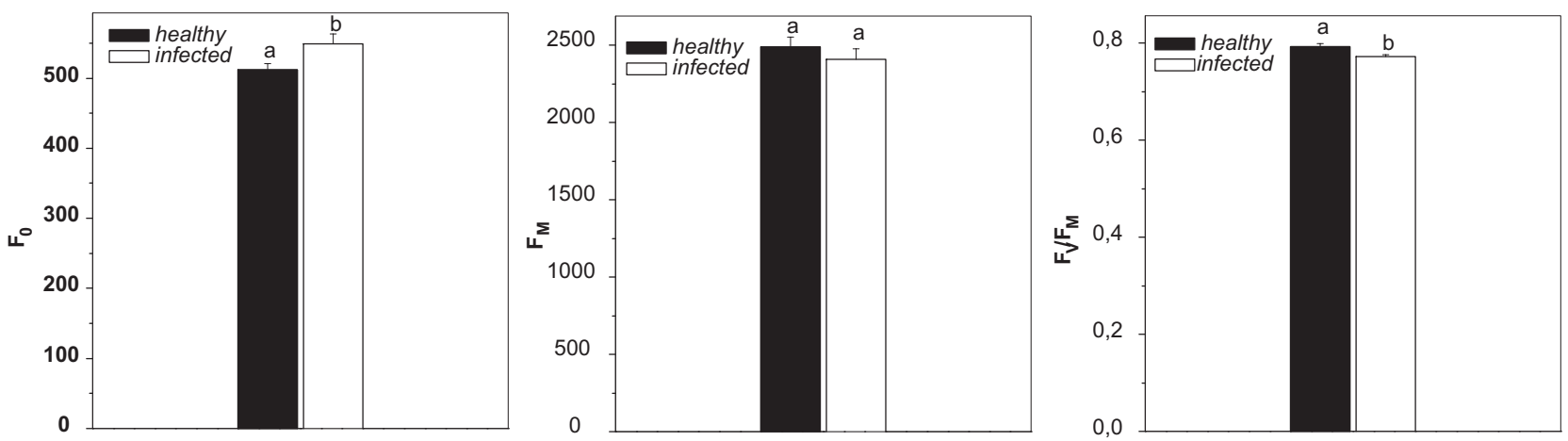

FIG 1 - Parameters of the chlorophyll fluorescence in healthy and Sugarcane yellow leaf virus (ScYLV) infected sugarcane (Saccharum spp.) plants. Leaves were dark-adapted for 50 min before readings, and the recording time was $5 \mathrm{~s}$ with an excitation light of about 3000 $\mu$ mol. $\mathrm{m}^{-2} \cdot \mathrm{s}^{-1}$. Results represent the mean $( \pm \mathrm{SD})$ of eighteen plants. $\mathrm{F}_{0}$ : Initial fluorescence; $\mathrm{F}_{\mathrm{V}}$ : Variable fluorescence $\mathrm{F}_{\mathrm{M}}$ : maximal fluorescence. The ratio $\mathrm{F}_{\mathrm{v}} / \mathrm{F}_{\mathrm{M}}$ correspond to the potential quantum efficiency of PSII. Means followed by different letters differ at $5 \%$ level by $\mathrm{T}$ Test.

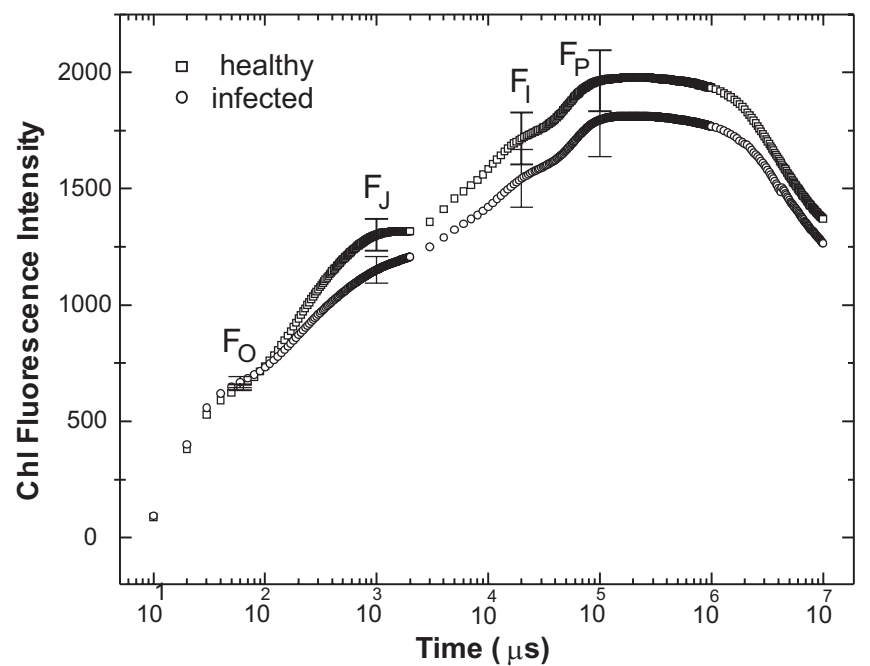

FIG. 2 - Kinetics of the fast chlorophyll fluorescence rise in healthy and Sugarcane yellow leaf virus (ScYLV) infected sugarcane (Saccharum spp.) plants. Two intermediate steps, $\left(\mathrm{F}_{\mathrm{J}}\right.$ and $\left.\mathrm{F}_{\mathrm{I}}\right)$ between initial and final fluorescence, are indicated to help visualise the differences in the filling up of the PQ pool. Results represent the mean $( \pm \mathrm{SD})$ of eighteen plants. Points were plotted using the Origin ${ }^{\circledR}$ 6.0 software.

contents of total soluble sugars, sucrose and reducing sugars. Sugar contents in leaves were increased by ScYLV infection. Relative to the leaves of healthy plants, sucrose was the sugar that accumulated most in the leaves of infected plants, followed by total soluble sugars and reducing sugars (Figure 6).

\section{DISCUSSION}

In the current study, we established that infection by ScYLV in sugarcane causes alterations in photosynthetic metabolism and disorders in plant carbohydrate metabolism. An imbalance of photosynthetic pigments in ScYLV infected plants should be predictable, particularly in plants showing severe yellowing symptoms. The classical symptoms caused

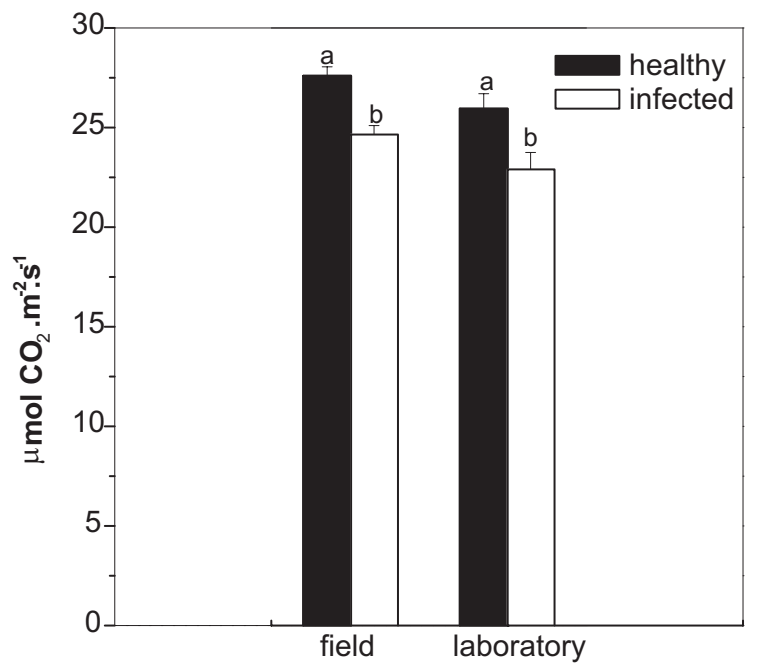

FIG. 3 - $\mathrm{CO}_{2}$ assimilation in healthy and Sugarcane yellow leaf virus (ScYLV) infected sugarcane (Saccharum spp.) plants under field and controlled conditions. Gas exchange measurements were performed from 11:50 AM to 2:30 PM at ambient temperature $\left(34,5-36,7{ }^{\circ} \mathrm{C}\right)$ and air $\mathrm{CO}_{2}$ concentrations under field conditions. Controlled conditions were $24{ }^{\circ} \mathrm{C}$ and PPFD of $1246 \pm 33 \mu \mathrm{mol} . \mathrm{m}^{-2} \cdot \mathrm{s}^{-1}$. Values correspond to the mean of eighteen plants per treatment \pm SD. Means followed by different letters differ at $5 \%$ level by $\mathrm{T}$ Test.

by plant viruses in their hosts are changes in chlorophyll synthesis and ruptures in the structure and function of chloroplasts (Goodman et al., 1986). The decrease in the ratio chl $a /$ chl $b$ in infected plants, however, seems to be a new issue on the effects of plant virus infection. Reductions in this ratio are usually verified in shade acclimated plants, and are described as indicative of increased grana stacking, reduced intergrana lamelae and higher $\mathrm{PS}_{\mathrm{II}} / \mathrm{PS}_{\mathrm{I}}$ ratio, which may result in a greater capacity for post-illumination ATP production (Tinoco-Ojangurensen \& Pearcy, 1995). Hence one can hypothesize that viral replication and nucleic acid synthesis may monopolize and cause high demands on energy in the form of ATP in infected cells, inducing alterations in the ratio $\operatorname{chl} a / \mathrm{chl} b$ and interfering with 
M.C. Gonçalves et al.

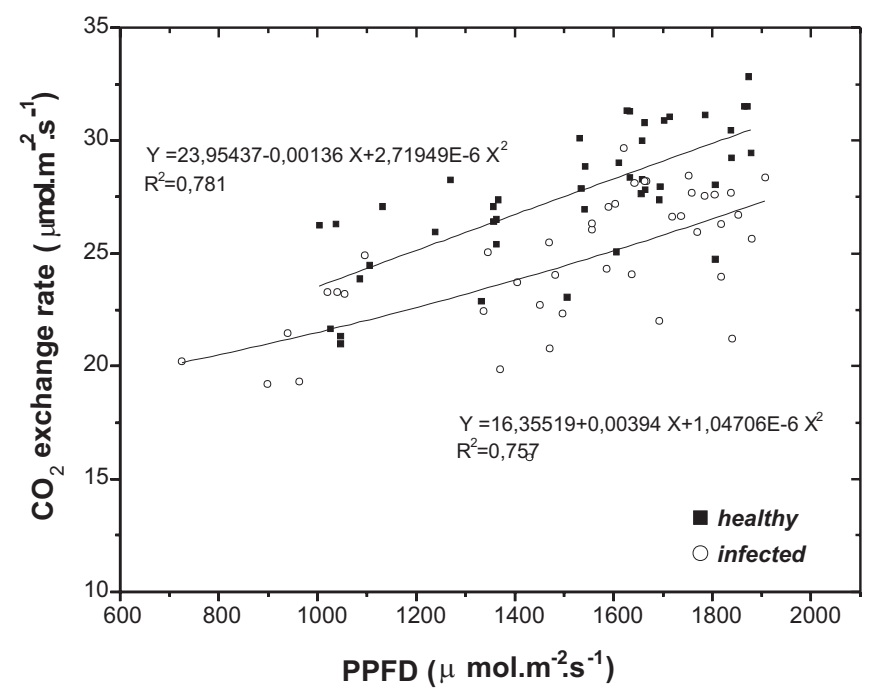

FIG. 4 - $\mathrm{CO}_{2}$ assimilation in healthy and Sugarcane yellow leaf virus (ScYLV) infected sugarcane (Saccharum spp.) plants under field conditions. Gas exchange measurements were performed from 11:50 AM to 2:30 PM at ambient temperature $\left(34,5-36,7^{\circ} \mathrm{C}\right)$ and air $\mathrm{CO}_{2}$ concentrations. Points correspond to the mean of eighteen plants per treatment and curves represent polynomial regression. Points and curves were plotted using the Origin ${ }^{\circledR} 6.0$ software.

photochemical activity of infected leaves.

The results arising from chlorophyll fluorescence analyses support the above hypothesis. The potential quantum yield of $\mathrm{PS}_{\mathrm{II}}$ was reduced in infected leaves, and the events leading to this observation seem to be caused by a reduction in the fraction of open $\mathrm{PS}_{\mathrm{II}}$ reaction centres. The increase in $\mathrm{F}_{0}$ and reductions in $\mathrm{F}_{\mathrm{M}}$ and in the ratio $\mathrm{F}_{\mathrm{V}} / \mathrm{F}_{\mathrm{M}}$ follow the pattern of the second component of a photo inhibitory process (Krause, 1988), associated with the development of symptoms by viral infection (Balachandran et al., 1997). These events are indicative of excessive photo protection and destabilisation of $\mathrm{PS}_{\mathrm{II}}$ turnover as a consequence of prolonged over-reduction of the photosynthetic electron transport. According to Asada (1994), these processes are not readily reversible and involve damage to D1 protein and other $\mathrm{PS}_{\mathrm{II}}$ reaction centre components. They probably are involved in intensification of symptoms by causing photosynthetic pigment photoxidation following imbalance in electron transport to $\mathrm{O}_{2}$ and over generation of reactive oxygen species (Asada, 1994). Taking into account the analysis of the fast chla fluorescence kinetics, we identified different phases of the electron transport in PS $_{\text {II }}$ influenced by viral infection. The fast chl $a$ fluorescence provides an experimental approach to assay the $\mathrm{PS}_{\mathrm{II}}$ reactions leading to the filling up of the PQ pool. This kind of analysis allows evaluation of the photosynthetic apparatus in vivo. In spite of this, the assay offers a restricted estimation over the $\mathrm{PS}_{\mathrm{II}}$ electron transport. Its combination with the analyses of $\mathrm{PS}_{\mathrm{II}}$ antennae photosynthetic pigments, to the gas exchange during photosynthesis and to the sugar contents in the photosynthetically active leaves allows a general overview of the interference of the viral infection in the photosynthetic process, from the photobioenergetic reactions to the availability of carbohydrates for phloem loading.

Gas exchange performance assays indicate that one or more steps in the process of $\mathrm{CO}_{2}$ assimilation may have been altered by virus infection. Once sugarcane has a $\mathrm{C}_{4}$ photosynthetic metabolism, it may incorporate $\mathrm{CO}_{2}$ with high efficiency, especially under temperatures close to $35^{\circ} \mathrm{C}$ and high irradiance (Salisbury and Ross, 1992). This feature is possible due to the capacity of sugarcane and other $\mathrm{C}_{4}$ plants to use the $\mathrm{CO}_{2}$ from decarboxilation of malate and aspartate in the bundle sheath, facilitating the production of 3-PGA (3phosphoglyceric acid) by ribulose-1,5-bisphosphate carboxylase/oxygenase (RUBISCO). Several photosynthetic enzymes depend on light and energy as ATP and NADPH for $\mathrm{CO}_{2}$ assimilation and reduction, which are less abundant in infected cells due to their mobilization during virus replication. The enzyme malate desidrogenase, which converts oxaloacetic acid to malate, is located in the chloroplasts, whose structure and organisation are supposedly impaired by the virus. The imbalances in the pigment contents and in the ratio $\mathrm{Chl} a / \mathrm{Chl} b$ indicate such alterations in these organelles may have influenced the gas exchange rates besides interfering in the filling up of the PQ pool.

The significant accumulation of sugars in leaves of infected plants is a possible effect of the virus on nonphotosynthetic processes, such as compartmentalization and metabolic transport via phloem. Luteoviruses are confined to the phloem tissue of its hosts, with sieve elements and companion cells frequently occupied (Francki et al., 1985). Sugar loading, mainly sucrose, and its distribution to the sinks require passage through these cells (Lalonde et al., 2003), which are somehow modified during virus movement through the phloem. Replication of the genome of positive sense single stranded RNA (ssRNA ${ }^{+}$) viruses occurs in the cytoplasm in close association with membranes. After replication, interactions between replicases and movement proteins (MPs) start the process of transporting viral genomes to the plasmodesmata for intercellular transport (Carrington et al., 1996); the MPs interact with the plasmodesmata changing its structure and functionality (Atkins et al., 1991). As previously noted, the accumulation of soluble sugars by virus infected or transgenic plants expressing viral proteins was proved to be an indirect effect of the MPs of TMV and PLRV (Lucas et al., 1996; Olesinski et al., 1996; Herbers et al., 1997). The primary mechanism seems to be an effect of the MP in the size exclusion limit (SEL) of the plasmodesmata in controlling phloem loading in infected plants. In fact, this viral protein contains domains that allow it to interact with plasmodesmata to potentiate cell-to-cell viral RNA transport (Lucas \& Gilbertson, 1994) and domains that influence processes involved in sugar storage, translocation and partitioning (Balachandran et al., 1995). Secondary mechanisms act at a stricter level, inhibiting sugar transport proteins and the cell wall invertase mediated inhibition of sugars (Herbers et al., 2000). The accumulation of soluble sugars may be involved 

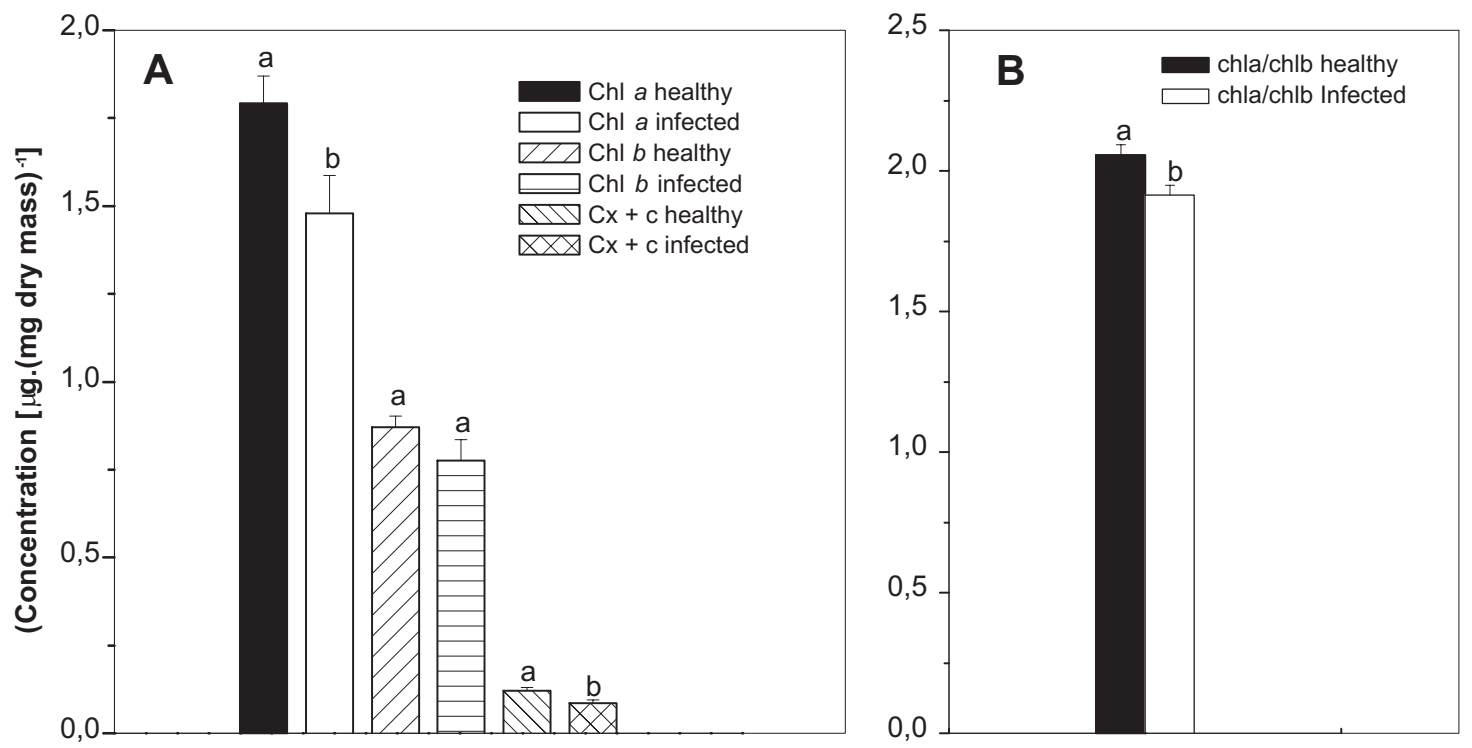

FIG. 5 - (A) Concentration of pigments in leaves of healthy and Sugarcane yellow leaf virus (ScYLV) infected sugarcane (Saccharum spp.) plants. The concentration of xanthophylls and carotenoids is indicated by $\mathrm{Cx}+\mathrm{c}$. (B) Ratio chla/chl $b$. Values in (A) and (B) correspond to the mean of eighteen plants \pm SD. Means followed by different letters differ at $5 \%$ level by T Test.

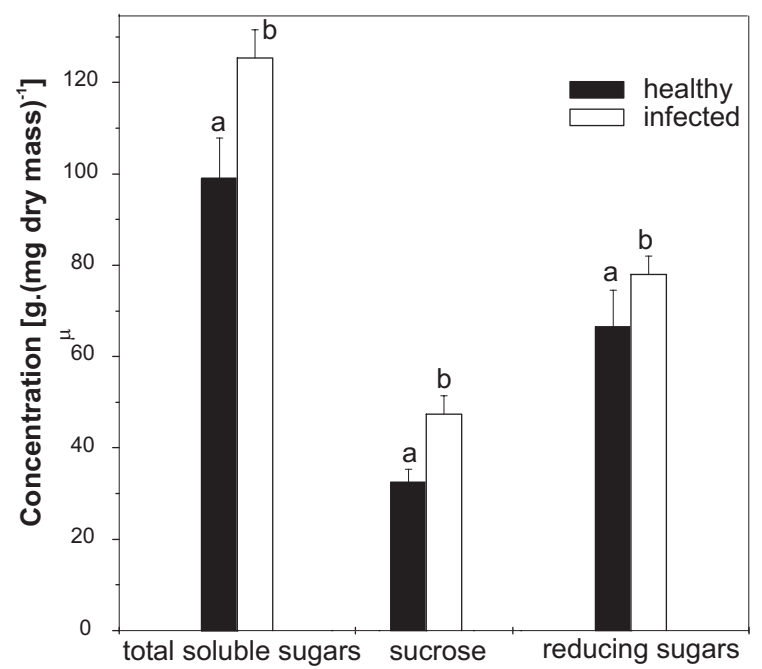

FIG. 6 - Carbohydrate contents in leaves of healthy and Sugarcane yellow leaf virus (ScYLV) infected sugarcane (Saccharum spp.) plants. Values correspond to the mean of eighteen plants \pm SD. Means followed by different letters differ at $5 \%$ level by $\mathrm{T}$ Test.

in gene regulation and, in our case, in tobacco transgenic plants as well which express the luteoviral MP of PLRV (Herbers et al., 1997) may lead to the repression of genes involved in the photosynthetic reduction of $\mathrm{CO}_{2}$.

This study brings insights to the indirect effects of viral infection in the photosynthetic apparatus and its correlation with previously known alterations in the metabolism of infected plants. Most of the observed changes are directly involved in supporting virus replication. Some of them, however, such as the accumulation of soluble sugars and the inhibitory feedback of genes involved in photosynthesis (Krapp \& Stitt, 1995) are possibly involved in host defence functions.

\section{ACKNOWLEDGMENTS}

We are grateful to Dr. Eduardo Caruso Machado, IAC, Campinas, for the use of the IRGA equipment and laboratory facilities for execution of gas exchange measurements.

\section{LITERATURE CITED}

ASADA, K. Production and action of active oxygen species in photosynthetic tissues. In: Foyer, C.H. \& Mullineaux, P.M. (Eds.), Causes of photoxydative stress and amelioration of defence systems in plants. CRC Press, Boca raton, FL. USA. 1994. pp.77-104.

ATKINS, D., HULL, R., WELLS, B., ROBERTS, K., MOORE, P. $\&$ BEACHY, R.N. The tobacco mosaic virus $30 \mathrm{~K}$ movement protein in transgenic tobacco plant is localized to plasmodesmata. Journal of General Virology 72:209-211. 1991.

BALACHANDRAN, S., HULL, R.J., VAADIA,Y., WOLF, S. \& LUCAS, W.J. Alteration in carbon partitioning induced by the movement protein of tobacco mosaic virus originates in the mesophyll and is independent of change in the exclusion size limit. Plant Cell Environment 18:1301-1310. 1995.

BALACHANDRAN, S., HURRY, V.M., KELLEY, S.E., OSMOND, C.B., ROBINSON, S.A., ROHOZINSKI, J., SEATON, G.G.R. \& SLIMS, D.A. Concepts of plant biotic stress. Some insights into the stress physiology of virus-infected plants, from the perspective of photosynthesis. Physiologia Plantarum 100:203-213. 1997.

BJÖRKMAN, O. \& DEMMIG, B. Photon yield of $\mathrm{O}_{2}$ evolution and chlorophyll fluorescence characteristics at $77 \mathrm{~K}$ among vascular plants of diverse origins. Planta 170:489-504. 1987.

CARRINGTON, J.C., KASSHAW, K.D., MAHAJAN, S.K. \& 
M.C. Gonçalves et al.

SHAAD, M.C. Cell-to-cell and long distance transport of viruses in plants. Plant Cell 8:1669-1681. 1996.

DUBOIS, M.K., GILLER, K.A., HAMILTON, J.K., RUBERS, P.A. \& SMITH, T. Corolimetric method for determination of sugars and related substances. Analytical Chemistry 28:350-56. 1956.

FRANCKI, R.I.B., MILNE, R.G. \& HATTA, T. Luteovirus group. In: Atlas of plant viruses, vol 1.Boca Raton, Fl: CRC Press. 1985. pp.137-152.

GOODMAN, R.N., KIRALY, Z. \& WOOD, K.R. The biochemistry and physiology of plant disease. Univ. Missouri Press, Columbia, MO, USA. 1986.

HERBERS, K., TACKE, E., HAZIREZAEI, M., KRAUSE, K.P., MELZER, M., ROHDE, W. \& SONNEWALD, U. Expression of a luteoviral movement protein in transgenic plants leads to carbohydrate accumulation and reduced photosynthetic capacity in source leaves. Plant Journal 12:1045-1056. 1997.

HERBERS, K., TAKAHATA, Y., MELZER, M., MOCK, H.-P., HAJIREZAEI, M. \& SONNEWALD, U. Regulation of carbohydrate partitioning during the interaction of Potato virus $\mathrm{Y}$ with tobacco. Molecular Plant Pathology 1:51-59. 2000.

HOFIUS, D., HERBERS, K., MELZER, M., OMID, A., TACKE, E., WOLF, S. \& SONNEWALD, U. Evidence for expression leveldependent modulation of carbohydrate status and viral resistance by the potato leafroll virus movement protein in transgenic tobacco plants. Plant Journal 28:529-543. 2001.

KRAPP, A. \& STITT, J. An evaluation of direct and indirect mechanisms for 'sink-regulation' of photosynthesis in spinach: Changes in gas exchange, carbohydrates, metabolites, enzyme activities and steady-state transcript levels after cold-girdling source leaves. Planta 195:313-323. 1995.

KRAUSE, G.H. Photoinhibition of photosynthesis. An evaluation of damaging and protective mechanisms. Physiologia Plantarum 74:566-574. 1988.

KRAUSE, G.H. \& WEIS, E. Chlorophyll fluorescence and photosynthesis: the basics. Annual Review Plant Physiology and Plant Molecular Biology 42:313-349. 1991.

LALONDE, S., TEGEDER, M., THRONE-HOLST, M., FROMMER, W.B. \& PATRICK, J.W. Phloem loading and unloading of sugars and amino acids. Plant Cell Environment 26:37-56. 2003.

LICHTENTHALER, H.K. \& WELLBURN, A.R. Determination of total carotenoids and chorophylls a and $\mathrm{b}$ of leaf extracts in different solvents. Biochemical Society Transactions 11:591-2. 1983.

LICHTENTHALER, H.K. \& RINDERLE, U. The role of chlorophyll fluorescence in the detection of stress conditions in plants. CRC Critical Reviews in Analytical Chemistry 19:S29-S85. 1988. (Abstract)

LUCAS, W.J. \& GILBERTSON, R. Plasmodesmata in relation to viral movement within leaf tissues. Annual Review of
Phytopathology 32:387-411. 1994.

LUCAS, W.F., BALACHANDRAN, S., PARK, J. \& WOLF, S. Plasmodesmal companion cell-mesophyll communication in the control over carbon metabolism and phloem transport: insights gained from viral movement proteins. Journal of Experimental Botany 47:1119-1128. 1996.

MAIA, I.G., GONÇALVES, M.C., ARRUdA, P. \& VEGA, J. Molecular evidence that Sugarcane yellow leaf virus (ScYLV) is a member of the Luteoviridae family. Archives of Virology 145:10091019. 2000.

MOONAN, F., MOLINA, J. \& MIRKOV, T.E. Sugarcane yellow leaf virus: An emerging virus that has evolved by recombination between Luteoviral and Poleroviral ancestors. Virology 269:156171. 2000.

OLESINSKI, A.A., ALMON, E., NAVOT, N. PERL A., GALUN, E., LUCAS, W.J. \& WOLF, S. Tissue specific expression of the tobacco mosaic virus movement protein in transgenic potato plants alters plasmodesmal function and carbohydrate partitioning. Plant Physiology 111:541-550. 1996.

OLIVEIRA, J.G., ALVES, P.L.C.A. \& MAGALHÃES, A.C. The effect of chilling on the photosynthetic activity in coffee (Coffea arabica $\mathrm{L}$.) seedlings. The protective action of chloroplastid pigments. Brazilian Journal of Plant Physiology 14:95-104. 2002.

SALISBURY, F.B.\& ROSS, C.W. Plant Physiology 4th ed. Wadsworth Publishing Company. Belmont, California. 1992.

SEO, S., OKAMOTO, M., IWAI, T., IWANO, M., FUKUI, K., ISOGAI A., NAGAJIMA, N. \& OHASHI, Y. Reduced levels of chloroplast FtsH protein in tobacco mosaic virus-infected tobacco leaves accelerate teh hypersensitive reaction. Plant Cell 12:917932. 2000.

STRASSER, R.J., SRIVASTAVA, A. \& GOVINDJEE. Polyphasic chlorophill a fluorescence transient in plants and cyanobacteria. Photochemistry and Photobiology 61:32-42. 1995.

TINOCO-OJANGUREN, C. \& PEARCY, R.W. A comparison of light quality and quantity effects on the growth and steady-state and dynamic photosyntetic characteristics of three tropical tree species. Functional Ecology 9:222-230. 1995.

VAN HANDEL, E. Direct microdetermination of sucrose. Analytical Biochemistry 22:280-83. 1968.

VAN KOOTEN, O. MEURS, C. \& VAN LOON, L.C. Photosynthetic electron transport in tobacco leaves infected with tobacco mosaic virus. Physiologia Plantarum 80:446-452. 1990.

VEGA, J., SCAGLIUSI, S.M.M. \& ULIAN, E.C. Sugarcane Yellow Leaf Disease in Brazil: Evidence of association with a luteovirus. Plant Disease 81:21-26. 1997.

ZAITLIN, M. \& HULL, R. Plant virus-host interactions. Annual Review of Plant Physiology 38:291-315. 1987. 